\title{
THE EXPRESSION OF NATION-BUILDING AND THE CHARACTER-BUILDING SPIRIT AS NATIONAL IDENTITY IN THE ISTIQLAL MOSQUE'S ARCHITECTURE
}

\author{
${ }^{1}$ Iqbal Ardiansyah ${ }^{2}$ Ir. Sudianto Aly, M.T. \\ ${ }^{1}$ Student in the Bachelor's (S-1) Study Program in Architecture at \\ Parahyangan Catholic University \\ ${ }^{2}$ Senior lecturer in the Bachelor's (S-1) Study Program in Architecture at \\ Parahyangan Catholic University
}

\begin{abstract}
A political regime generally possesses an identity and has insight into nationally idealistic cultural values. Its expression can be observed in the art and physical architecture that blossoms in its era. This insight gives birth to national identity. The formation of national identity itself originated from several dimensions, namely the sub-national dimension, the personal dimension, and the supra-national dimension. In the transition between the Netherland-East Indies and the Republic of Indonesia, Indonesia as a new country possessed ideals in the formation of physical architectures that can represent its national identity. This insight is realized in detail within nation-building and character-building ideas within several mega-projects pioneered by the Old-Order government. One of them was the Istiqlal Mosque as a national house of worship. The expression of Istiqlal Mosque architecture cannot be separated from the dimensions of national identity formation in architecture. The focus of this research is on the observation of Istiqlal Mosque architecture. Indicators of the national identity's expression in Istiqlal Mosque architecture are: the discussion of national-identity dimensions in architecture (national-identity dimension - sub-national dimension, national-identity dimension - personal identity and national-identity dimension- supra-national identity). The discussions of expression in architecture that can be achieved through visual composition formation are (a) domination, (b) repetition, and $(C)$ continuity in composition of one architectural object. The object of architecture was further examined, arranged by form and material, general design principles, contextual relations, and physical, semantic and spatial organization of an architectural object. The Istiqlal Mosque is one example of an architectural product from the previous political regime that can profoundly and critically sharpen our thoughts concerning the Indonesian nation's identity on the national and state level.
\end{abstract}

Keywords: national identity, nation-building and character-building, sub-national dimension, personal dimension, supra-national dimension, Istiqlal Mosque

\section{EKSPRESI SEMANGAT NATION-BUILDING DAN CHARACTER-BUILDING SEBAGAI IDENTITAS NASIONAL PADA ARSITEKTUR MASJID ISTIQLAL}

\author{
${ }^{1}$ Iqbal Ardiansyah ${ }^{2}$ Ir. Sudianto Aly, M.T. \\ ${ }^{1}$ Mahasiswa S1 Program Studi Arsitektur Universitas Katolik Parahyangan. \\ ${ }^{2}$ Dosen Pembimbing S1 Program Studi Arsitektur Universitas Katolik Parahyangan.
}

${ }^{1}$ Corresponding Author: iqbal.ardiansyah@aiesec.net 


\begin{abstract}
Abstrak- Suatu rezim politik umumnya memiliki identitas dan pandangan nilai-nilai kebudayaan ideal secara nasional. Hal tersebut ekspresinya dapat diperhatikan dari seni dan fisik arsitektur yang berkembang pada masanya. Pandangan inilah yang menjadi asal terbentuknya identitas nasional. Pembentukan identitas nasional itu sendiri berasal dari beberapa dimensi, diantaranya dimensi subnasional, dimensi personal, dan dimensi supranasional. Pada masa transisi kekuasaan Hindia-Belanda menjadi Republik Indonesia, sebagai negara yang baru Indonesia juga memiliki cita-cita dalam pembentukan hal-hal fisik arsitektur yang dapat merepresentasikan identitas nasionalnya. Pandangan ini diwujudkan lebih detail dalam ide nation-building dan character-building dan terdapat beberapa mega-proyek yang diprakarsai oleh pemerintahan Orde Lama. Salah satunya Masjid Istiqlal sebagai rumah ibadah nasional. Ekspresi dari arsitektur Masjid Istiqlal tidak terlepas dari dimensi-dimensi pembentuk identitas nasional dalam arsitektur. Fokus penelitian dititik-beratkan pada observasi arsitektur Masjid Istiqlal. Hal-hal yang menjadi indikator ekspresi identitas nasional dalam arsitektur Masjid Istiqlal adalah: Pembahasan mengenai dimensi-dimensi identitas nasional dalam arsitektur (dimensi identitas nasional- identitas subnasional, dimensi identitas nasional - identitas personal dan dimensi identitas nasional - identitas supranasional). Pembahasan mengenai ekspresi dalam arsitektur yang dapat dicapai melalui pembentukan komposisi visual (a) dominasi, (b) repetisi, dan (c) kesinambungan dalam komposisi pada satu objek arsitektur. Objek arsitektur ditelaah lebih jauh, disusun atas bentuk dan material, prinsip rancangan umum, hubungan dengan konteks, dan organisasi fisik, semantik, dan spasial pada satu objek arsitektur. Masjid Istiqlal sebagai salah satu contoh produk arsitektur pada rezim politik yang lalu, yang secara dalam dan kritis mempertajam pemikiran mengenai identitas Bangsa Indonesia dalam skala kenegaraan ataupun nasional.
\end{abstract}

Kata-kata kunci: identitas nasional, nation-building dan character-building, dimensi subnasional, dimensi personal, dimensi supranasional, Masjid Istiqlal.

\title{
1 PENDAHULUAN
}

Suatu rezim politik umumnya memiliki identitas dan pandangan nilai-nilai kebudayaan ideal secara nasional yang ekspresinya dapat diperhatikan dari seni dan fisik arsitektur yang berkembang pada masanya. Pandangan inilah yang menjadi asal terbentuknya identitas nasional. Akan tetapi, identitas nasional bukanlah satu kajian yang dapat dilihat dalam pandangan satu dimensi, melainkan kajian multi dimensi dikarenakan kompleksitas dari unsur negara itu sendiri.

Lawrence J. Vale (2008) dalam buku Architecture, Power, and National Identity menjabarkan lagi dimensi-dimensi pembentuk dari identitas nasional dalam arsitektur, antara lain adanya pengaruh faksi-faksi yang lebih spesifik dari kedudukan nasional atau negara yang disebut dengan subnasional, dimensi dari orang-orang yang langsung terlibat dalam penentuan kebijakan politik negara termasuk arsitektur yang di prakarsai negara atau dimensi personal, dan juga hal-hal yang menjadi visi utopis yang statusnya lebih tinggi dari kedudukan nasional atau negara itu sendiri atau supranasional.

Masjid Istiqlal yang merupakan satu diantara beberapa bangunan yang termasuk ke dalam proyek tersebut, beserta bangunan-bangunan skala kenegaraan lain diantaranya; Monumen Nasional, Stadion Utama Senayan, Tugu Selamat Datang, Hotel Indonesia, Gedung Bank Indonesia, Jembatan Semanggi, dan seabagainya mengekspresikan identitas nasional yang dicanangkan dalam gagasan nation-building dan character-building.

Rencana pembangunan Masjid Istiqlal ditujukan untuk memberi identitas kepada mayoritas masyarakat Indonesia yang memeluk agama Islam dan terlebih lagi pada saat tersebut belum terdapat sebuah masjid skala nasional yang representatif bagi masyarakat Indonesia di ibu kota Jakarta yang sekaligus menjadi rumah ibadah nasional masyarakat Indonesia. 
Identitas nasional pada Masjid Istiqlal juga tidak terlepas dari dimensi-dimensi identitas nasional yang dijabarkan oleh Vale. Tetapi tidak semua dimensi diekspresikan dalam satu bentuk arsitektur.

Identitas dalam arsitektur memfokuskan pada beberapa kajian yang akan peneliti tinjau pada arsitektur Masjid Istiqlal. Tiga fokus utama kajian terhadap identitas dalam arsitektur menurut Casey (1993) adalah tempat (place), manusia (people), dan makna (meaning).

Masjid Istiqlal bertempat pada ibukota negara Indonesia, Jakarta dan terletak tidak berjauhan dengan kompleks pemerintahan nasional, termasuk Istana Presiden Republik Indonesia. Masjid Istiqlal memiliki peran sebagai masjid nasional, dimana hari raya umat muslim dalam skala kenegaraan diselenggarakan.

Masjid Istiqlal dibangun sebagai bentuk rasa syukur bangsa Indonesia yang pada masa pemerintahan Presiden Soekarno, baru merdeka dan telah terlepas dari masa kolonialisme. Oleh karena itu, Masjid Istiqlal dipersembahkan kepada seluruh Bangsa Indonesia.

Bangsa Indonesia ditentukan berdasarkan ketentuan hukum dan bukan berdasarkan suku, etnis, golongan ataupun kepercayaan. Untuk menjabarkan siapa saja yang dimaksud dengan bangsa Indonesia, penulis mengacu pada pasal 2, UU No. 12 tahun 2006 mengenai kewarganegaraan yang berbunyi: "Yang menjadi Warga Negara Indonesia adalah orangorang Bangsa Indonesia Asli dan orang-orang bangsa lain yang disahkan dengan undangundang sebagai Warga Negara.".

Merupakan sebuah fakta fungsi Masjid Istiqlal memiliki afiliasi dengan umat Islam di Indonesia. Akan tetapi, Masjid Istiqlal tidak bersifat eksklusif namun inklusif yang membuka umat golongan kepercayaan lain untuk dapat mengunjunginya.

Identitas arsitektur Masjid Istiqlal berhubungan langsung dengan makna yang terkandung didalamnya. Seperti yang sudah kita ketahui dari teori yang dijelaskan oleh Lawrence J. Vale (2008) bahwa identitas nasional merupakan masalah yang kompleks, dan terdapat dimensi-dimensi yang membentuk keseluruhannya. Maka dari itu penulis merasa perlu untuk menelaah identitas nasional pada dimensi-dimensi yang lebih spesifik. Dimensi tersebut adalah Identitas NasionalSubnasional, Identitas Nasional-Personal, dan Identitas Nasional-Supranasional.

Penulis akan menggunakan teori oleh Torabi dan Brahman (2013) untuk melakukan observasi faktor-faktor pembentuk identitas berdasarkan kategorisasi dimensi arsitektur, yaitu dengan memperhatikan bentuk, material prinsip rancangan umum, hubungan dengan konteks, organisasi fisik, semantik dan spasial, pada rancangan arsitektur Masjid Istiqlal.

\section{ANALISA}

\subsection{ANALISIS DIMENSI SUBNASIONAL}

Dalam proses penciptaan identitas nasional dalam proyek-proyek nation-building dan character-building, tidak terlihat ekspresi elemen subnasional. Hal ini dimungkinkan karena syarat utama pembentukan komposisi visual, tidak tercapai, yaitu tidak adanya dominasi, pengulangan bentuk atau repetisi, dan kesinambungan dalam komposisi.

Beberapa elemen-elemen yang berasal dari dimensi subnasional akan dilakukan analisis untuk memperhatikan seberapa besar pengaruhnya pada faktor-faktor yang membentuk satu identitas, yaitu: 


\subsubsection{BENTUK}

Bangunan Masjid Istiqlal berfungsi sebagai rumah ibadah umat Islam di Indonesia. Oleh karena itu, peranan sistem kepercayaan dalam agama Islam dan teori mengenai arsitektur masjid akan berpengaruh kepada penerapan bentuk-bentuk preseden dalam proses perancangan Masjid Istiqlal dan ekspresi yang dihasilkan.

Dari perkembangan sejarah, masjid memiliki beberapa tipologi yang dipengaruhi oleh pola sosio-kultural, dan geografis. Tipologi yang paling lazim antara lain adalah gaya Iran atau Asia Tengah, gaya Anatolia (Turki), gaya India atau Asia Selatan, gaya Cina atau Asia Timur, gaya Spanyol atau Afrika Utara dan gaya Asia Tenggara. Aplikasi bentuk lebih mengarah pada faktor assumed blood ties dibanding religion.

Arsitektur Masjid Istiqlal tidak menunjukkan ekspresi yang menyerupai salah satu dari tipologi masjid tersebut. Masjid Istiqlal, memiliki sebuah kubah tunggal yang berukuran raksasa menyerupai tipologi Anatolia tetapi juga memiliki selasar yang dikelilingi emperan seperti tipologi Asia Selatan. Perancangan tata masa Masjid Istiqlal merupakan kombinasi elemen primer dan sekunder arsitektur Masjid terhadap modernisme berupa regionalisme abstrak.

Kubah merupakan elemen yang termasuk kedalam elemen tersier pada arsitektur masjid, atau bersifat mubah dalam filsafat teologi Islam (tidak memiliki nilai ibadah). Sebagian besar masjid-masjid terawal sendiri di timur-tengah saat masa pemerintahan Muhammad dan sahabatsahabatnya (Rushadun Caliphate) tidak memiliki kubah pada atapnya. Kubah mulai di populerkan pada saat pemerintahan Kekaisaran Ottoman yang semulanya diadopsi dari peninggalan bentuk arsitektur Greco-Roman.

Pada Masjid Istiqlal, terdapat dua buah kubah, satu kubah besar dan satu buah kubah kecil. Kubah utama lebih menyerupai bentuk kubah Ottoman yaitu berbentuk setengah bola, dan kubah yang lebih kecil menyerupai kubah Asia Selatan atau kubah mughal yaitu bentuk yang hampir mendekati bentuk bola. Dapat diperhatikan masjid tipologi Asia Timur dan Asia Tenggara tidak mengikuti aplikasi bentuk kubah tetapi mengikuti bentuk atap yang dianggap sakral pada sosiokultur wilayahnya.

Adopsi elemen arsitektural yang mempengaruhi bentuk lainnya adalah minaret. Minaret atau manara berasal dari kata nar atau nur yang secara etimologis dalam linguistik Arab memiliki arti "cahaya". Hal ini dikarenakan minaret pada awalnya berfungsi sebagai mercusuar, dimana pada bagian puncak berfungsi sebagai penerangan di tepi pantai. Minaret memiliki pergeseran fungsi yang dapat membantu untuk menyerukan azan atau panggilan ibadah. Karena fungsi tersebut minaret memiliki sifat sunnah dalam filsafat teologi Islam (memiliki nilai ibadah tetapi bukan suatu obligasi).

Juga terdapat berbagai tipologi minaret pada arsitektur masjid yang menjadi preseden pada masa dan letak geografis tertentu. Minaret Masjid Istiqlal secara keseluruhan mendekati dengan tipologi minaret Ottoman, tetapi dalam bentuk yang lebih di simplifikasi. Tipologi masjid Asia Tenggara pada awalnya tidak memiliki minaret, minaret mulai diaplikasikan saat pengaruh Ottoman. Salah satunya minaret Masjid Demak yang ditambah kemudian.

Bagian teras dan selasar juga bukan elemen bentuk yang lazim terdapat pada tipologi masjid Asia Tenggara. Teras pada masjid tipologi Asia Tenggara tidak memiliki keterkaitan dengan bagian dari bangunan, sementara pada Masjid Istiqlal masa emperan (shuffah) dan teras menjadi sebuah satu kesatuan rancangan arsitektur. Teras merupakan satu anjuran pada bangunan masjid yang berguna untuk pelaksanaan ibadah salat pada hari-hari besar. Beberapa tipologi masjid 
bahkan memiliki proporsi teras yang jauh lebih besar dibanding bangunan yang beratap, seperti tipologi masjid Asia Selatan, dan Asia Tengah.

\subsubsection{MATERIAL}

Material-material yang digunakan dalam rancangan arsitektur Masjid Istiqlal, tidak memiliki hubungan dengan dimensi subnasional sebagai pembentuk identitas nasional. Faktor sistem kepercayaan, ataupun asumsi keterkaitan darah dengan rezim-rezim yang lalu tidak mengharuskan satu material yang spesifik dalam pahamnya.

\subsubsection{PRINSIP RANCANGAN UMUM DAN KESESUAIAN DENGAN KONTEKS}

Terdapat beberapa hal yang didasarkan dari dimensi subnasional dalam pembentukan identitas nasional dan aplikasinya dalam prinsip rancangan umum, antara lain: sistem kepercayaan dan asumsi keterkaitan darah dengan rezim dan pemerintahan masa lalu.

Sistem kepercayaan didalam teologi Islam tidak mengharuskan adanya pakem-pakem yang mengikat dalam rancangan masjid. Hanya orientasi arah bangunan yang menghadap ke kiblat dan area imam yang berada didepan mamum dalam proses pelaksanaan ibadah secara berjamaah.

Prinsip rancangan yang lebih memiliki andil besar dalam perancangan didasarkan dari prinsip rancangan keraton jawa (keterkaitan darah dengan rezim yang mendahului). Tatanan kawasan Masjid Istiqlal dan sekitarnya memilih untuk tetap meromantisasi unsur tradisional yang berdasar pada tatanan masa keraton Jawa dalam tatanan kawasannya, yaitu komposisi tiga elemen arsitektur yang saling berdekatan: istana keraton, alun-alun, dan masjid keraton. Hal ini salah satu faktor yang mempengaruhi diputuskannya Taman Wijaya Kusuma sebagai lokasi pembangunan Masjid Istiqlal dan bukan lokasi alternatif di Jalan Thamrin.

Tiga tatanan elemen masa ini masih dapat diperhatikan di beberapa kompleks keraton yang masih terjaga, diantaranya yang peniliti gunakan untuk observasi adalah citra satelit dari wilayah di sekitar Keraton Kasepuhan di Cirebon (Figur 1), Keraton Ngayogyakarta Hadiningrat di Yogyakarta (Figur 2), dan Keraton Surakarta Hadiningrat di Solo (Figur 3).

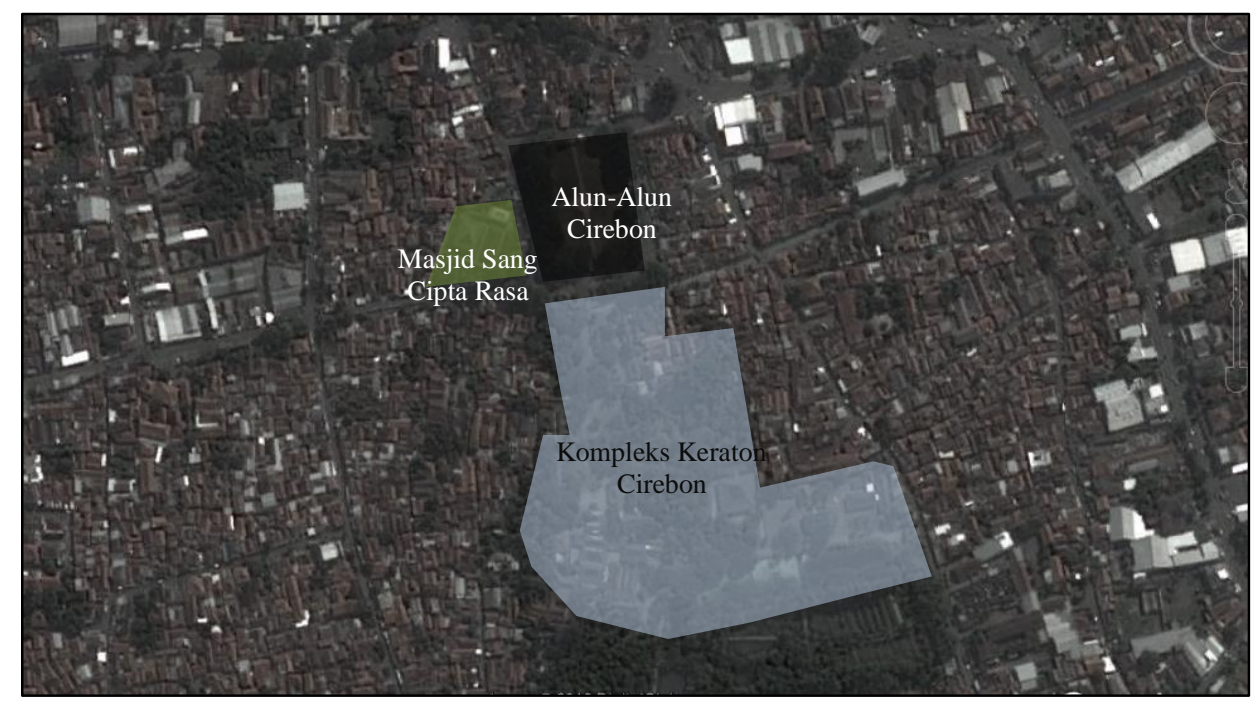

Figur 1 Citra Satelit Kawasan Keraton Kasepuhan, Cirebon

(sumber: google earth) 


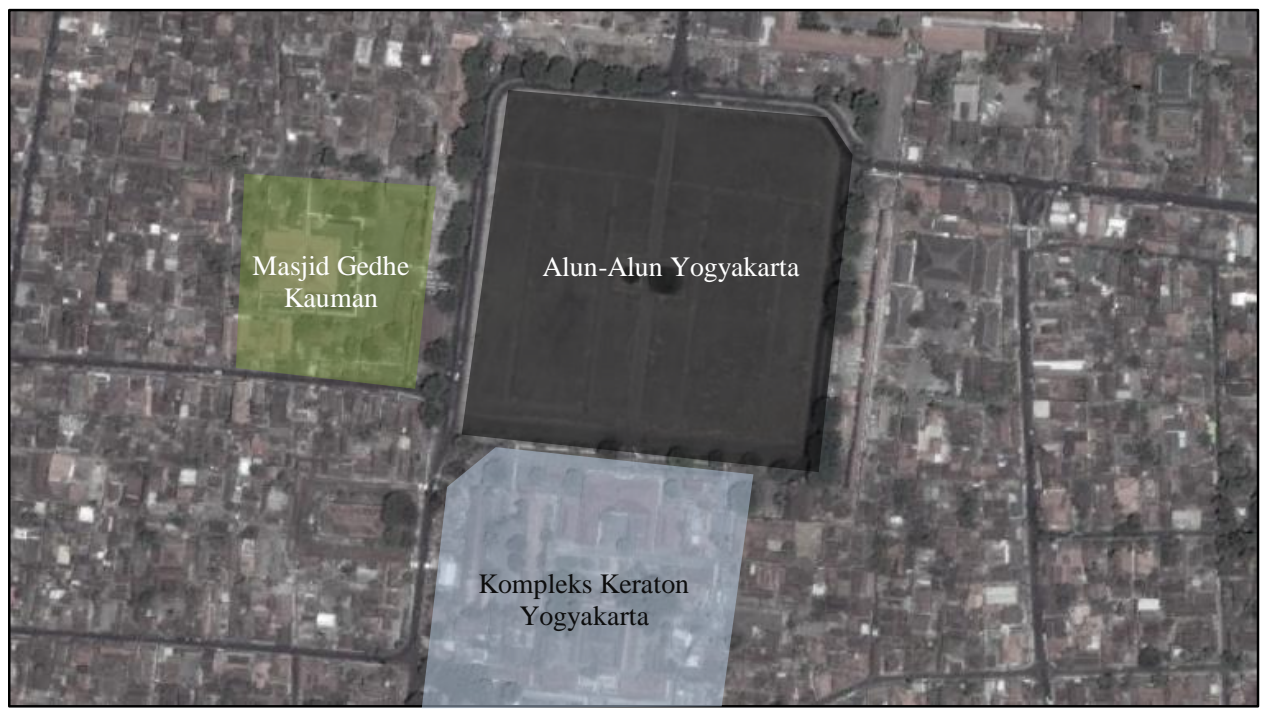

Figur 2 Citra Satelit Kawasan Keraton Ngayogyakarta Hadiningrat, Yogyakarta (sumber: google earth)

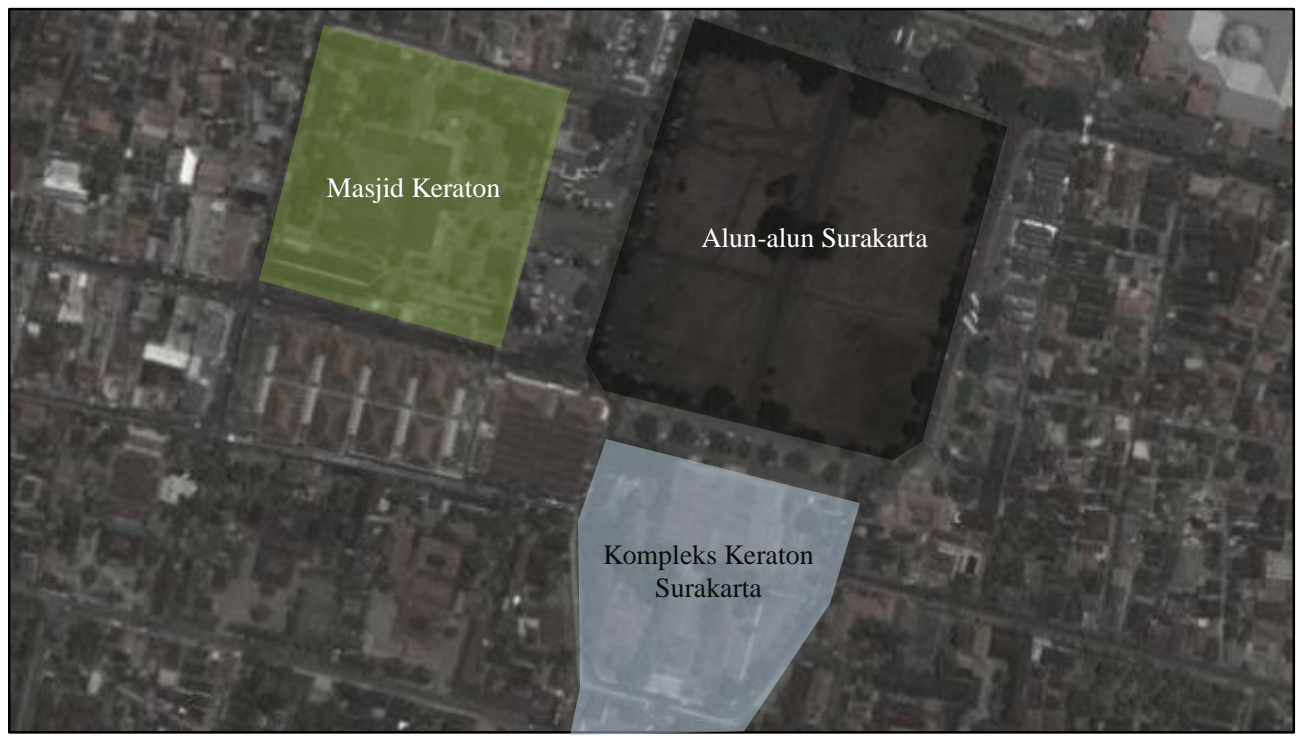

Figur 3 Citra Satelit Kawasan Keraton Surakarta Hadiningrat, Solo (sumber: google earth)

Ketiga elemen ini, antara istana keraton, alun-alun, dan sebuah bangunan yang bersifat suci (dalam konteks ini, rumah ibadah Masjid) pada tatanan kawasan Masjid Istiqlal di analogikan dalam skala kenegaraan, yaitu: Istana Merdeka, Lapangan Monumen Nasional, dan Masjid Istiqlal itu sendiri seperti yang dapat diperhatikan pada citra satelit kawasan Masjid Istiqlal pada Figur 4. 


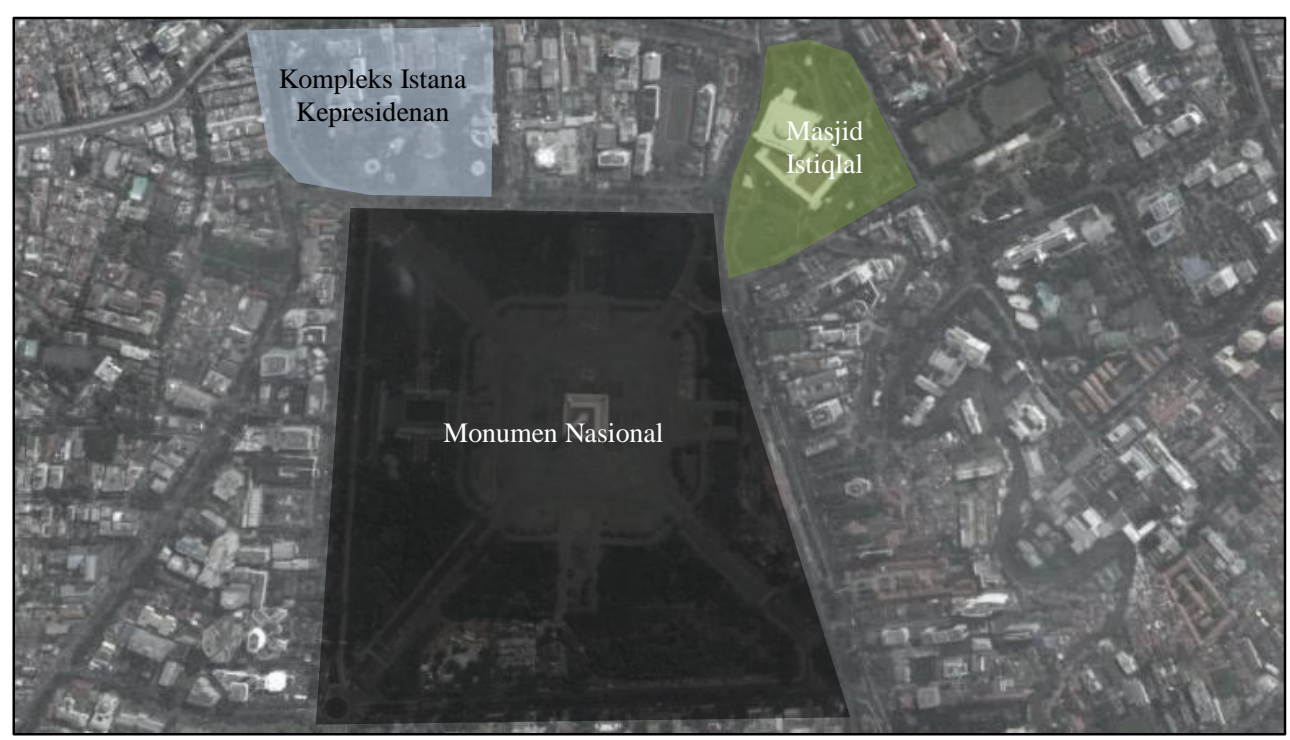

Figur 4 Citra Satelit Kawasan Masjid Istiqlal

(sumber: google earth)

\subsubsection{ORGANISASI FISIK, SEMANTIK, DAN SPASIAL}

Terdapat hal yang bersifat minor pada rancangan organisasi fisik, semantik, dan spasial yang didasarkan dari dimensi subnasinoal, yaitu elemen tersier atau elemen yang tidak memiliki nilai esensial dan hanya berupa simbolisme yang tidak memiliki nilai urgensi sama sekali. Dalam hukum Islam elemen tersier walaupun sering diasosiasikan dengan arsitektur masjid bersifat mubah, boleh ada tetapi bukan suatu keharusan dan tidak memiliki nilai amalan dalam ajaran teologi Islam. Elemen tersier ini antara lain simbol bulan dan bintang, kubah, kaligrafi, ukiran muqarnas, dan maqsurah.

Pada awal dirancang, secara keseluruhan Masjid Istiqlal memiliki elemen tersier yang sangat minimal. Elemen tersier yang terdapat pada rancangan hanya tiga kaligrafi berukuran besar yang bertuliskan "Allah" dan "Muhammad" serta kaligrafi Alquran surat At-Thaha ayat 14. Terdapat pula elemen repetisi brise soleil yang digunakan sebagai kisi-kisi masa emperan. Setelah beberapa kali mengalami renovasi, pada tahun 2012 bagian dinding kiblat ditambahkan dengan ukiran floral dan geometris bergaya timur tengah (peradaban Islam melarang adanya ukiran menyerupai makhluk hidup dan manusia), walaupun secara keseluruhan, bagian ukiran tidak mendominasi dan tidak terdapat repetisi pada bagian-bagian lain di Masjid Istiqlal.

Bentuk atap Masjid Istiqlal menggunakan kubah lebih mengekspresikan bentuk-bentuk masjid yang berada di luar kawasan kepulauan Nusantara dan Asia Timur dan lebih menyamai dengan ekspresi bentuk atap masjid di kawasan Timur Tengah. Masjid memiliki minaret walaupun tidak menyerupai tipologi minaret preseden yang telah ada. Masa emperan dan teras dibangun dikarenakan terdapat anjuran untuk melaksanan ibadah di lapangan pada hari-hari besar.

Prinsip rancangan umum yang mengarahkan orientasi banguan utama ke arah kiblat, rancangan bentuk masa emperan dan minaret dipengaruhi oleh dimensi subnasional yang berasal dari sistem kepercayaan, dikarenakan adanya kewajiban dan penganjuran elemen tersebut dalam teologi Islam yang berkaitan dengan arsitektur (bersifat wajib dan sunnah). 
Tetapi, rancangan bentuk kubah, organisasi semantik yang berupa ukiran pada bagian dinding kiblat, kaligrafi pada dinding kiblat dan interior kubah tidak dipengaruhi oleh sistem kepercayaan, tetapi lebih dipengaruhi oleh rasa keterkaitan ikatan darah dikarenakan elemenelemen tersebut lebih bersifat sosio-kultur dan didalam sistem kepercayaan Islam sendiri bersifat mubah atau tidak memiliki nilai ibadah.

Tabel 1. Hasil Analisis Dimensi Subnasional

\begin{tabular}{|l|l|c|c|c|}
\hline $\begin{array}{c}\text { Faktor-Faktor Pembentuk } \\
\text { Identitas }\end{array}$ & \multicolumn{1}{|c|}{ Dimensi Subnasional } & D* & R* & KK* \\
\hline \multirow{2}{*}{ Bentuk } & Kubah & $\bullet$ & - & $\bullet$ \\
\cline { 2 - 5 } & Minaret & - & - & $\bullet$ \\
\cline { 2 - 5 } & Teras dan Masa Emperan & $\bullet$ & - & $\bullet$ \\
\hline Material & (tidak berkaitan) & $\bullet$ & N/A & N/A \\
\hline $\begin{array}{l}\text { Prinsip Rancangan Umum } \\
\text { dan Hubungan dengan } \\
\text { Konteks }\end{array}$ & Orientasi kiblat pada bangunan utama & & & - \\
\cline { 2 - 5 } & Adaptasi tatanan masa keraton jawa & $\bullet$ & - & - \\
\hline $\begin{array}{l}\text { Organisasi Fisik, } \\
\text { Semantik, Spasial }\end{array}$ & Kaligrafi & & & \\
\cline { 2 - 5 } & Ornamen Ukiran & - & - & - \\
\hline
\end{tabular}

$*(\mathrm{D}=$ Dominasi, $\mathrm{R}=$ Repetisi, $\mathrm{KK}=$ Kesesuaian dengan Komposisi $)$

\subsection{ANALISIS PERSONAL}

Dimensi personal dalam identitas nasional adalah keterlibatan seorang pribadi berpengaruh atau tokoh yang dapat menentukan haluan politik dan budaya negara dapat dilakukan secara eksplisit ataupun implisit. Tokoh tersebut bisa seorang arsitek, pihak yang mendanai dan mensposori proyek skala kenegaraan, atau politisi itu sendiri. Pada kasus ini, tokoh yang memiliki pengaruh paling besar dalam pembentukan identitas nasional Masjid Istiqlal itu sendiri adalah Presiden Soekarno sebagai juri sayembara Masjid Istiqlal dan juga pencetus ide nation-building dan character-building itu sendiri.

Proses perancangan Masjid Istiqlal memakan waktu yang cukup panjang. Dimulai dari tahun 1950 hingga dilakukannya pemancangan tiang pertama pada tahun 1961. (Rizal, 2005) yang melakukan studi mengenai pandangan arsitektur Bung Karno menyatakan terdapatnya transisi pandangan arsitektur Bung Karno dari Periode Sang Padma Arsitek (1945-1959) menuju Periode Sang Arsitek Maestro (1959-1965). Pandangan Bung Karno bergerak yang awalnya kerap melakukan eksplorasi terhadap budaya dan tradisi Indonesia menjadi seorang yang menganut paham internasionalisme. Oleh karena itu, pengaruh modernisme yang sedikit condong mengarah ke gaya internasionalisme terlihat jelas dalam ekspresi Masjid Istiqlal.

\subsubsection{BENTUK}

(Hitchcock, 1992) dalam buku The International Style menjabarkan beberapa prinsip yang dimiliki oleh bangunan bergaya modern internasional. Dalam penjabarannya, peneliti akan mencoba melakukan komparasi teori terhadap arsitektur Masjid Istiqlal sendiri. 
Prinsip pertama dalam bangunan bergaya modern internasional adalah bangunan berupa volume dan bukan blok masa, atau dengan kata lain arsitektur kulit. Masa bangunan bergaya modern internasional tidak terikat dengan struktur yang berfungsi sebagai cangkang (blok masa). Kulit bangunan memberi kesan permukaan (surface) tetapi bukan bagian strukturnya sendiri.

Prinsip pertama dari internasionalisme tidak diaplikasikan pada Masjid Istiqlal, dimana struktur bangunan pada Masjid Istiqlal juga sekaligus berperan sebagai elemen struktural yang membentuk garis-garis vertikal pada fasadnya. Walaupun begitu, bentuk masih mengikuti paham modernisme yaitu bentuk-bentuk geometris.

Prinsip kedua pada arsitektur International Style adalah concerning regularity atau kepedulian terhadap keteraturan. Keteraturan dalam arsitektur berhubungan dengan nilai-nilai fungsionalisme dengan memperhatikan tatanan yang memiliki ritme.

Hal ini juga bertujuan sebagai konsiderasi terhadap faktor ekonomi dimana keteraturan dalam tatanan bentuk membentuk pola-pola yang modular sehingga efisiensi material lebih dapat diperkirakan.

Regularity sendiri bersifat relatif, akan tetapi apabila kita perhatikan dalam aplikasinya di Masjid Istiqlal, bagian struktur masa bangunan utama ataupun masa sekunder (masa emperan) memiliki keteraturan struktur yang jelas. Terdapat permainan aditif dan subtraktif, tetapi secara keseluruhan rekayasa bentuk memiliki ritme yang konsisten. Hal ini menciptakan pola-pola yang modular sehingga material bangunan dapat kembali digunakan dan sisa-sisa limbah material yang dihasilkan tidak banyak.

\subsubsection{MATERIAL}

Pemikiran mengenai material yang digunakan dalam Masjid Istiqlal dicetuskan oleh Presiden Soekarno. Masjid Istiqlal merupakan masjid yang dibangun pada fase yang cukup panjang sebagai masjid bergengsi untuk merepresentasikan umat islam di Indonesia dan ditujukan untuk menjadi masjid yang dirancang untuk tahan terhadap perkembangan zaman. Dalam pidato Soekarno pada tanggal 24 Agustus 1961 yang juga sekaligus merupakan tanggal pemancangan tiang pertama Masjid Istiqlal, beliau mengatakan:

"Indonesia harus belajar menjadi bangsa yang besar. Bangsa yang besar tidak boleh memiliki sebuah masjid kayu beratap genteng untuk kota besar seperti Jakarta yang menjadi pusat Indonesia, diperlukan masjid yang semewah mungkin, yang menjadi tempat ibadah lima puluh ribu, enam puluh ribu, tujuh puluh ribu orang dan menggunakan bahan bangunan yang akan bertahan selama ratusan, bahkan ribuan tahun".

Oleh karena itu penggunaan material pada Masjid Istiqlal didominasi oleh materialmaterial yang tahan terhadap zaman. Bahan-bahan yang berasal dari metal pun menggunakan metal baja stainless yang tidak berkarat hingga sekarang, termasuk pada kisi-kisi SPSM, bagian plafond dan enam ratus keran pada area wudu.

\subsubsection{PRINSIP RANCANGAN UMUM DAN HUBUNGAN DENGAN KONTEKS}

Rancangan Masjid Istiqlal yang dipengaruhi kuat oleh karakter pribadi Bung Karno, antara lain: gaya modern internasional dari Masjid Istiqlal itu sendiri, material yang diaplikasikan dalam Masjid Istiqlal dan aplikasi teknologi dalam arsitektur Masjid Istiqlal merupakan keseluruhan dari prinsip perancangannya itu sendiri, yang sebagian besar telah dijabarkan dalam poin-poin yang lain. 


\subsubsection{ORGANISASI FISIK, SEMANTIK, DAN SPASIAL}

Prinsip ketiga dan yang terakhir dalam arsitektur International Style adalah menghindari elemen-elemen aplikasi dekoratif atau avoidance of applied decoration. International Style merupakan kritik terhadap gaya-gaya arsitektur sebelumnya dimana ornamen dekoratif dinilai terlalu eksesif dan berlebihan.

Prinsip ketiga juga diaplikasikan dalam arsitektur Masjid Istiqlal, dimana pada saat awal dibangun ornamen dekoratif yang terdapat hanya pada kaligrafi dan bagian-bagian lain dalam keseluruhan bangunan merupakan bagian yang bersifat fungsionalis termasuk brise soleil yang memiliki peran sebagai sirip penangkal sinar matahari (SPSM). Oleh karena itu, organisasi fisik dan semantik pada Masjid Istiqlal sangat minim dengan elemen-elemen dekoratif.

Dimensi personal didasarkan pada pandangan arsitektur Presiden Soekarno yang memiliki pengaruh kuat dalam rencana pembangunan Masjid Istiqlal. Pemikiran ini didasarkan dari pandangan periode 1959-1965, atau periode Sang Arsitek Maestro. Soekarno bergerak mengarah ke gaya modern internasionalisme, maka kajian kualitatif ini didasarkan pada prinsip perancangan gaya modern internasional.

Dari tabel 2 yang merupakan hasil analisis dimensi personal, dapat diperhatikan hampir seluruh aspek yang merupakan pandangan dari Ir. Soekarno memiliki dominasi bentuk, repetisi desain dan kesesuaian dengan komposisi secara keseluruhan dan bahkan esensi utama dari pembentukan komposisi sendiri.

Tabel 2. Hasil Analisis Dimensi Personal

\begin{tabular}{|c|c|c|c|c|}
\hline $\begin{array}{l}\text { Faktor-faktor Pembentuk } \\
\text { Identitas }\end{array}$ & Dimensi Personal & $\mathrm{D}^{*}$ & $\mathrm{R}^{*}$ & $\mathrm{KK}^{*}$ \\
\hline \multirow[t]{2}{*}{ Bentuk } & Bentuk-bentuk geometris sesuai paham modernisme & $\bullet$ & • & $\bullet$ \\
\hline & Modularisme & $\bullet$ & • & • \\
\hline Material & $\begin{array}{l}\text { Aplikasi material yang tahan terhadap zaman (baja } \\
\text { stainless dan marmer) }\end{array}$ & $\bullet$ & $\bullet$ & $\bullet$ \\
\hline $\begin{array}{l}\text { Prinsip Rancangan Umum } \\
\text { dan Hubungan dengan } \\
\text { Konteks }\end{array}$ & $\begin{array}{l}\text { Penerapan rancangan gaya International Style secara } \\
\text { terpadu }\end{array}$ & $\bullet$ & $\bullet$ & $\bullet$ \\
\hline $\begin{array}{l}\text { Organisasi Fisik, } \\
\text { Semantik, dan Spasial }\end{array}$ & (tidak memiliki hubungan langsung) & N/A & N/A & $\mathrm{N} / \mathrm{A}$ \\
\hline
\end{tabular}

*(D = Dominasi, $\mathrm{R}=$ Repetisi, $\mathrm{KK}=$ Kesesuaian dengan Komposisi $)$

\subsection{ANALISIS SUPRANASIONAL}

Dimensi supranasional adalah dimensi yang hubungannya bukan berasal dari golongan atau pribadi, tetapi mengejar sesuatu yang lebih tinggi lagi dibandingkan negara, yaitu visi-visi utopisnya. Identitas nasional yang berkaitan dengan supranasional ditujukan untuk menunjukkan progres ekonomi dan kemampuan mencapai kapabilitas global. Identitas supranasional secara implisit merupakan negasi dari pembentukan identitas itu sendiri, dimana idealisme yang dikedepankan adalah keteraturan yang dicapai melalui efektifitas politik, dan keadilan sosial. 


\subsubsection{BENTUK}

Dimensi supranasional tidak memiliki bentuk-bentuk yang spesifik dalam representasi nilai yang terkandung dikarenakan supranasional sendiri lebih mengarah ke hal-hal yang bersifat metafisik dibanding fisik. Sementara bentuk pada umumnya adalah satu hal yang bersifat tangible atau terukur.

\subsubsection{MATERIAL}

Material yang digunakan pada hampir keseluruhan interior dan eksterior rancangan Masjid Istiqlal adalah marmer. Pada awal perancangan, terdapat rencana menggunakan marmer putih yang di ekspor dari Italia. Keterbatasan dana akhirnya memutuskan marmer yang digunakan adalah marmer lokal, dari area pertambangan marmer di Tulung Agung. Pemilihan penggunaan material yang terbatas dan berasal dari dalam negeri dapat dimaknai sebagai kemandirian ekonomi dalam pembentukan identitas nasional Indonesia.

Pemilihan atap kubah dan negasi terhadap atap limas tumpang tiga atau atap tumpang sari bukan bertujuan untuk mengidentikkan Masjid Istiqlal dengan tipologi masjid-masjid yang berasal dari Timur Tengah atau Asia Tengah dan Selatan, melainkan pendekatan pragmatis yaitu penerapan teknologi teknologi yang terbarukan. Salah satunya adalah teknologi kubah setengah bola dengan kerangka polyhedron yang di impor dari Jerman Barat dengan diameter 45 meter.

\subsubsection{PRINSIP RANCANGAN UMUM}

Prinsip rancangan umum memiliki porsi paling besar dalam membangun identitas nasional yang didasarkan pada dimensi supranasional. Efektifitas politik menjadi salah satu hal yang krusial bagi kestabilan suatu bangsa yang baru. Bangsa yang baru terbentuk apalagi setelah masa kolonialisme umumnya berasal dari bangsa yang majemuk dan memiliki banyak golongan subnasional. Rezim pemerintahan orde lama menyadari kemungkinan terjadinya friksi dari salah satu fraksi subnasional.

Pada awal mula eksistensi Republik Indonesia pernah terjadi beberapa pemberontakan oleh kelompok-kelompok yang ingin memaksakan idealisme kelompoknya menjadi haluan nasional, dua diantaranya pemberotakan PKI di Madiun dan pemberontakan Darul Islam di Jawa Barat. Hal ini menjadi alasan dibutuhkan satu elemen yang dijadikan sakral sebagai simbolisme persatuan nasional, yaitu Monumen Nasional. Terdapat dua sumbu yang menjadi orientasi masa pada Masjid Istiqlal, yaitu sumbu yang mengarah ke Kabah dan sumbu yang mengarah ke Monumen Nasional.

Bangunan utama dimana aula salat terletak berorientasi ke kabah sebagai kibal umat Islam, masa selasar yang mengelilngi emperan dan masa dimana kubah kecil terletak berorientasi ke Monumen Nasional. Hal ini merupakan penemuan yang kontras dengan kepentingan subnasional, dimana efisiensi ruang akan menjadi lebih maksimal apabila orientasi seluruhnya mengarah ke kiblat.

\subsubsection{ORGANISASI FISIK, SEMANTIK, DAN SPASIAL}

Organisasi fisik, semantik, dan spasial lebih diasosiasikan dengan visi-visi utopis soial. Salah satu visi utopis sosial yang menjadi dasar negara adalah Indonesia sebagai negara yang rukun dalam beragama, lokasi dipilih berdekatan dengan Katedral Jakarta. Pandangan view menuju katedral juga tidak terblokir dari pelataran teras Masjid Istiqlal. 
Pada hari-hari besar kedua kepercayaan, kebutuhan lahan parkir diakomodasi oleh tapak Masjid Istiqlal atau Katedral Jakarta secara bergantian. Masjid Istiqlal di intensikan tidak hanya dapat diakses oleh umat Islam saja, tetapi terbuka untuk semua orang untuk melakukan kunjungan ataupun studi.

Ekspresi keadilan sosial lain yang tercermin dalam arsitektur Masjid Istiqlal yaitu mengenai kedudukan wanita dalam masyarakat Indonesia yang diekspresikan dari layout area pria dan area wanita aula utama salat. Konstitusi Indonesia melihat wanita dan pria setara dimata hukum dan wanita memiliki kesempatan yang sama besarnya dengan pria di bidang politik.

Hal ini diekspresikan dari layout aula utama Masjid Istiqlal dimana area salat wanita sejajar dengan area salat pria. Pembagian area salat adalah sisi kiri-kanan dan bukan depanbelakang seperti kebanyakan layout masjid pada umumnya.

Bentuk merupakan satu kajian observasi yang bersifat fisik, sementara objek kajian dimensi supranasional merupakan hal-hal yang bersifat filsafat dan metafisik, sementara bentuk dapat dipersepsikan menurut subjek yang mengamati sehingga tidak terdapat kebenaran tunggal antar satu bentuk dan bentuk lainnya. Hal ini menjadi alasan bentuk menjadi faktor yang tidak relevan dalam proses penelitian.

Dimensi supranasional dalam proses pembentukan identitas nasional berkaitan dengan visivisi utopis satu bangsa dalam melihat diri mereka sendiri. Aplikasi material pada Masjid Istiqlal menunjukkan hal-hal tersebut. Seperti penggunaan material marmer sebagai finishing yang dinilai banyak orang sebagai status kemewahan untuk menunjukkan kemampuan finansial negara, atau dengan kata lain visi utopis Indonesia dalam bidang ekonomi. Sama halnya dengan kerangka polyhedron pada kubah yang sanggup membentangi area sepanjang 45 meter, yang menunjukkan visi utopis Indonesia dalam bidang teknologi.

Prinsip rancangan umum yang berkaitan dengan dimensi supranasional adalah orientasi masa emperan, masa bangunan sekunder dan teras yang menghadap ke Monumen Nasional apabila ditarik sumbu garis lurus. Orientasi ini merupakan pernyataan bahwa persatuan bangsa dan negara merupakan sebuah prioritas dan visi utopia politik dimana faksi-faksi subnasional tidak mengganggu stabilitas secara politik.

Organisasi fisik, semantik, dan spasial memfokuskan kepada visi-visi utopis secara sosial dan kemanusiaan. Pembebasan pandangan menuju Katedral Jakarta menunjukkan toleransi antar umat dalam bernegara, dan area salat wanita dan pria yang sejajar menunjukkan kesetaraan hak dan kewajiban tanpa memedulikan jenis kelamin dalam perannya berdasarkan konstitusi negara Indonesia.

Tabel 3. Hasil Analisis Dimensi Supranasional

\begin{tabular}{|c|c|c|c|c|}
\hline $\begin{array}{l}\text { Faktor-Faktor Pembentuk } \\
\text { Identitas }\end{array}$ & Dimensi Supranasional & $\mathrm{D}^{*}$ & $\mathrm{R}^{*}$ & $\mathrm{KK}^{*}$ \\
\hline Bentuk & (tidak memiliki hubungan langsung) & N/A & N/A & $\mathrm{N} / \mathrm{A}$ \\
\hline \multirow[t]{2}{*}{ Material } & $\begin{array}{l}\text { Material finishing menggunakan marmer yang berasal dari } \\
\text { Tulung Agung }\end{array}$ & $\bullet$ & $\bullet$ & $\bullet$ \\
\hline & $\begin{array}{l}\text { Teknologi kerangka polyhedron yang di impor dari } \\
\text { Jerman Barat }\end{array}$ & - & - & $\bullet$ \\
\hline
\end{tabular}




\begin{tabular}{|l|l|c|c|c|}
\hline $\begin{array}{l}\text { Prinsip Rancangan Umum } \\
\text { dan Hubungan dengan } \\
\text { Konteks }\end{array}$ & $\begin{array}{l}\text { Orientasi masa emperan yang menghadap ke Monumen } \\
\text { Nasional }\end{array}$ & $\bullet$ & - & $\bullet$ \\
\hline $\begin{array}{l}\text { Organisasi Fisik, } \\
\text { Semantik, dan Spasial }\end{array}$ & $\begin{array}{l}\text { Organisasi fisik yang membebaskan view kearah Katedral } \\
\text { Jakarta }\end{array}$ & - & - & $\bullet$ \\
\cline { 2 - 5 } & Organisasi spasial area salat pria dan wanita & $\bullet$ & - & $\bullet$ \\
\hline
\end{tabular}

$*(\mathrm{D}=$ Dominasi, $\mathrm{R}=$ Repetisi, $\mathrm{KK}$ = Kesesuaian dengan Komposisi $)$

\section{KESIMPULAN}

Masjid Istiqlal merupakan sebuah proyek raksasa nasional pada era pemerintahan Orde Lama dimana, Indonesia sebagai negara yang baru ingin mengekspresikan nilai-nilai bersama kepada dunia dan sekaligus sebagai pengarah untuk bangsa Indonesia sendiri kedalam bentuk fisik arsitektur. Visi ambisius Orde Lama tersebut disebut juga dengan istilah pembangunan karakter bangsa atau nation-building dan character-building.

Identitas nasional di manapun, termasuk visi nation-building pada arsitektur Masjid Istiqlal merupakan peleburan dimensi-dimensi yang membentuknya. Dimensi tersebut dijabarkan oleh Lawrence J. Vale (2008) antara lain dimensi subnasional, personal dan supranasional.

Ekspresi semangat nation-building dan character-building sebagai identitas nasional pada arsitektur Masjid Istiqlal merupakan kajian dalam penelitian ini. Analisis telah menunjukkan beberapa faktor yang mengindikasikan bahwa ekspresi Masjid Istiqlal sebagian besar dipengaruhi oleh dimensi personal, yaitu visi dari Bung Karno sebagai Presiden Republik Indonesia pada zaman tersebut dan juga dimensi supranasional dimana para pendiri bangsa memiliki cita-cita dan utopia mengenai masa depan pembangunan Indonesia.

Pada akhirnya, peneliti dapat mengambil kesimpulan bahwa ekspresi semangat nationbuilding dan character-building sebagai identitas nasional pada arsitektur Masjid Istiqlal secara dominan dan sebagian besar dibentuk dari dimensi personal. Dimensi supranasional menyusul kemudian, dan dimensi yang paling sedikit terdapat pengaruhnya dalam ekspresi Masjid Istiqlal adalah dimensi subnasional.

Penelitian ini membahas Masjid Istiqlal sebagai salah satu contoh produk arsitektur pada rezim politik yang lalu, yang secara dalam dan kritis mempertajam pemikiran mengenai identitas Bangsa Indonesia dalam skala kenegaraan ataupun nasional.

Bagi peneliti selanjutnya, diharapkan mengadakan penelitian lebih lanjut akan pengaruhpengaruh arsitektur kenegaraan yang tidak menegasikan dimensi-dimensi pembentuk identitas nasional itu sendiri khususnya dimensi supranasional yang menciptakan identitas negara dari halhal yang memiliki kedudukan diatas negara sendiri seperti politik dan sosial demi pencapaian identitas dan sense of place. Apabila terdapat hal-hal yang bersangkutan dengan kegiatan perbaikan dan pembaharuan bangunan kenegaraan yang dibangun pada zaman dulu agar nilai-nilai yang dituju tidak hilang dapat diterjemahkan berbeda dari persepsi pengguna bangunan.

Bagi pembaca, diharapkan agar dengan membaca penelitian ini bisa menjadi lebih peka akan ilmu arsitektur, pengaruhnya terhadap budaya dan nilai-nilai bersama secara nasional. Diharapkan pula agara pembaca bisa mengerti akan asal usul dari pembentukan identitas nasional sendiri dan dapat menumbuhkan semangat nasionalisme. 


\section{DAFTAR PUSTAKA}

Abel, Chris. 1997. Architecture \& Identity. Oxford: Architectural Press.

Budiharjo, Eko. 1997. Perkembangan Arsitektur dan Pendidikan Arsitektur di Indonesia. Yogyakarta: Gajah Mada University Press.

Curtis, William. 1985. Regionalism in Architecture. Singapura: Concept Media.

Fanani, Achmad. 2009. Arsitektur Masjid. Yogyakarta: Penerbit Bentang.

Hitchcock, Henry Russell; Johnson, Philip. 1992. The International Style. New York: W.W. Norton Company

Nas, Peter J.M. 2009. Masa Lalu dalam Masa Kini: Arsitektur di Indonesia. Jakarta: Gramedia Pustaka Utama.

Rizal, J.J. 2005. Bung Karno Sang Arsitek: Kajian Artistik Karya Arsitektur, Tata Ruang Kota, Interior, Kria, Simbol, Mode Busana, dan Teks Pidato 1926-1965. Depok: Komunitas Bambu.

Torabi, Zoherh; Brahman, Sara. 2013. Effective Factors in Shaping the Identity of Architecture. Zanjan: IDOSI Publication.

Vale, Lawrence J. 2008. Architecture, Power, and National Identity. Abingdon: Routledge. Wennberg, Harriet. 2015. In Place: A Study of Building and Identity. Oxford: Seacourt Ltd.

Wondoamiseno, R.A. 1991. Regionalisme dalam Arsitektur Indonesia: Sebuah Harapan. Yogyakarta: Yayasan Rupadatu. 